Published in Journal of Small Business and Enterprise Development, Vol. 9, No 4, pp 349-357, Autumn, 2002.

\title{
TAKING CONTROL OF WORD-OF-MOUTH MARKETING: THE CASE OF AN ENTREPRENEURIAL HOTELIER
}

\author{
Dr. David Stokes* \\ Dr. Wendy Lomax \\ * Author for correspondence \\ Kingston Business School, Kingston Hill, Kingston-upon-Thames, KT2 7LB \\ Tel. 0208547 7218; fax 0208547 7140; email d.stokes@kingston.ac.uk
}




\title{
TAKING CONTROL OF WORD-OF-MOUTH MARKETING: THE CASE OF AN ENTREPRENEURIAL HOTELIER
}

\begin{abstract}
Marketing in entrepreneurial contexts, such as small business, relies heavily on word of mouth (WOM) recommendations for customer acquisition. However we know little about how WOM processes work for small firms, or how owner-managers can influence them. This case study of an entrepreneurial owner of an independent hotel is used to illustrate problems associated with WOM, and potential strategies to overcome them. The ownermanager researched existing hotel customers through face-to-face interviews and a questionnaire. The results confirmed the importance of WOM, but found two sets of dissonance. One was between input WOM types and sources, the other between output WOM content and targets. The owner-manager improved the effectiveness of WOM communications through a variety of interventions. Demonstrating that WOM can be an effective part of a marketing strategy for a small firm.
\end{abstract}

\section{MANAGERIAL AND POLICY IMPLICATIONS}

- Small and medium sized enterprises (SMES) can influence the informal process of wordof-mouth communication.

- The first stage for the entrepreneur is to investigate how WOM process work in the context of the specific business.

- Entrepreneurs need to understand the input WOM types and sources, and the output WOM content and targets. They should also examine the relationship between these data looking for potential dissonance. 
- Owner-managers should seek triggers to stimulate positive word-of-mouth communications and develop processes to minimise negative word-of-mouth communication and its impact

Keywords: WOM communications, entrepreneurship, tourism, marketing

\section{INTRODUCTION}

The case study presented here follows the theme of making marketing concepts and principles more relevant in entrepreneurial contexts, summarised as 'putting entrepreneurship into marketing' (Day, 1998:5). Word of mouth (WOM) marketing is examined in the context of a small business venture to see how marketing principles fit with entrepreneurial practice. It is increasingly recognised that marketing as perceived and undertaken by entrepreneurs is different to the concepts presented in conventional marketing textbooks (e.g. Kotler, 2000). Small business owners shy away from formalised promotional campaigns and rely instead on WOM to develop the customer base through recommendations. These recommendations are seen as the primary source of new customers (e.g. Stokes et al., 1997). Coming as they may from customers, suppliers or other referral groups, little is known about how WOM processes work in this context, nor about the methods by which owner-managers could seek to manage them.

\section{Defining WOM}

There is substantial literature on the significance of WOM in the broader context. Arndt's (1967) definition of a WOM communication is often used: 
"Oral person-to-person communication between a receiver and a communicator whom the person perceives as non-commercial, regarding brand, product or a service".

There are two particular issues which arise from wide acceptance of this definition:

Firstly it involves face-to-face, oral contact between a communicator and a receiver. This needs updating in the context of electronic forms of communication; for example, the Internet is a growing source of recommending and complaining communications (Buttle, 1998). Equally letters, faxes and e-mail could represent WOM opportunities.

Secondly, the communicator is perceived to be independent of the product or service under discussion. As the consumer becomes increasingly cynical about the true independence of third party advice (Culligan, 1995), WOM can be more influential than well-researched printed sources of product information such as 'Which?' (Herr et al., 1991). Paradoxically, companies are increasingly attempting to harness the power of WOM by intervening in the recommending process. Relationship marketing proponents advocate incentives to customers for recommending friends and families, and the development of reciprocal referrals amongst organisations. Member Get Member (MGM) schemes are commonplace; network marketing relies almost entirely on the use of personal contacts to develop sales. It can be argued that recommendations based on such activities are not fully independent but do seem to have an effect on WOM activity (Bayus, 1985; Payne et al., 1995). This led Buttle (1998:101) to conclude that:

"Perhaps all that distinguishes WOM is that it is uttered by sources who are assumed by receivers to be independent of corporate influence".

Although this well may be true, the use of the term "uttered" suggests a limitation to the oral communication suggested by Arndt. We would suggest that the word "uttered” is replaced by the more generic "communicated", allowing for the inclusion of a greater variety of 
methods, particularly new media. All interpersonal interaction offers potential for WOM communication, regardless of medium. We use the following definition of WOM:

All interpersonal communication regarding products or services where the receiver regards the communicator as impartial.

WOM can be described in terms of direction, valence and volume. Its direction can be input (into the decision-making process) or output (of the purchase process), (Bone 1995). Its valence can be positive or negative. Its volume relates to the number of people to which the message is relayed. For the purposes of this case study, the following points are salient:

- Input WOM becomes especially relevant where the product is characterised by experience and credence qualities, rather than the more easily assessed search qualities (Zeithaml et al., 1992). Consumers seek recommendation and referral to reduce their perception of risk in an intangible arena (Herr et al., 1991). The credibility of input WOM increase with visual support (Gatignon and Robertson, 1971).

- Output WOM offers different characteristics. Negative output WOM appears to be capable of greater volume than positive output WOM (TARP, 1989). The problem of dissatisfaction is compounded by the fact that this may be concealed from the supplier. Frequency of reported complaints invariably underestimate real levels of consumer dissatisfaction and therefore, the likelihood of negative WOM communications (Richins, 1983). This is complicated by the emotional context of conversations; consumers display a preference to pass on bad news in negative environments and good experiences in positive ones (Heath, 1996). However buyers are still more likely to pass on bad rather than good, news without necessarily alerting the supplier to the problem through a complaint. The management of negative WOM through effective complaints procedures can therefore influence not only existing customer loyalty, but customer acquisition as well (Fornell and Wernerfelt, 1988). This point seems to be ignored by many companies. 
Output WOM is stimulated by the degree of involvement a buyer has with the product, or supplying organisation. For example, consumers consider their experiences with hospitality products and services as interesting conversation topics and are in the habit of telling others about their experiences concerning tourism and new restaurants (Haywood, 1989). This is particularly relevant in this hotel case study.

\section{WOM and small business}

A number of studies have indicated that the most important source of new customers for small firms is recommendations from existing customers (e.g. Barclays Review, 1997). Stokes et al., (1997) found that reliance on WOM from customers and other sources such as suppliers, applied across most sectors and ages of SMEs. This led some owners to conclude that they did not need to promote their business by conventional marketing methods, as sufficient new business came from recommendations.

For many owner-managers, reliance on recommendations is realistic as it is more suited to the resources of their business. Referrals incur few, if any, additional direct costs. Most owner-managers prefer the slow build up of new business which WOM marketing generates, since large increases in demand are problematic.

However, complete reliance on WOM has disadvantages. It limits growth since reliance on informal communications restricts organisations to the limits of those networks. A small business dependent on recommendations for new customers is limited to those markets in which its sources of recommendations operate. WOM is perceived to be uncontrollable; some owners see few opportunities to influence recommendations, other than providing the 
best possible service. In practice, opportunities for effective management of WOM will be missed.

\section{Entrepreneurial management of WOM}

Successful entrepreneurs find ways of encouraging referrals and recommendations by proactive methods. For example, Shaw (1997) demonstrated that small graphic designers used bartering, hospitality, flexible pricing and differential handling of work to help in the development of their referral networks. A feeling of involvement or participation with a small business, can also encourage customer loyalty and recommendations. From a study of lawyers' practices in the USA, File et al. (1992) suggested that the intensity and variety of client participation during the service delivery process was predictive of positive word-ofmouth and referrals. Stokes (1997) found an association between parents' involvement in their children's primary schools, and their propensity to recommend that school.

Although several authors assert that WOM can be managed, research-based evidence of effective WOM marketing by small firms is limited. Although there is little practical proof, Wilson (1991) asserts that:

"You can be just as organised, thoughtful and systematic about word-of-mouth advertising as about media buys"

Earlier, Engel et al. (1969) had concluded research can identify that influential opinion leaders. Haywood (1989) suggested that active listening and effective questioning are a necessary prelude to encouraging referrals from such influencers. Other examples of successful WOM marketing are largely anecdotal (e.g. Misner, 1994). There is little 
substance to guide entrepreneurs who wish to intervene in WOM processes to achieve some control.

\section{METHODOLOGY}

As described, previous research indicates that WOM processes take place in ways that should influence marketing strategies. It suggests that management should take a more systematic view of WOM communications, although examples of researched processes are limited. Although there is general agreement that WOM is the principal source of new business acquisition for SMEs, little is known about, if and how, entrepreneurs have successfully incorporated WOM strategies into their marketing. This study documents one entrepreneur's attempt.

Our approach is that of a longitudinal case study, using two main sources of data. We describe the attempts of an owner-manager of an independent hotel to formulate a marketing strategy to increase occupancy rates. We draw on qualitative data derived from interviews with the owner-manager and his own qualitative data collected for his dissertation on a parttime MBA programme. These multiple sources of data facilitate triangulation.

The case study approach is particularly suited to this type of research problem where we examine a phenomenon in a particular context. By pulling the two data sets together, our research develops a deeper understanding of how the WOM process works, and shows how a practical implementation of the implications positively affects a small business at minimal cost. Figure 1 shows the chronology and sources of the data gathered.

Figure 1: Chronology And Sources Of Data Gathered 
Our research

DEPTH

INTERVIEW WITH

OWNER-

MANAGER
Owner-Managers Research

AUGUST 1997

DEPTH

INTERVIEW WITH

OCTOBER 1997

5 HOTEL GUESTS

PILOT QUESTIONNAIRE

WITH 15 HOTEL

OWNER-MANAGERS

RESEARCH

OCTOBER 1998

HOTEL GUESTS (48\%

RESPONSE)
QUESTIONNAIRE TO 250
DEPTH INTERVIEW

WITH OWNER-

MANAGER

\section{Owner-Manager's Research}

Before conducting his research, the owner-manager developed several research propositions based on a trawl of academic literature. He felt that there were three characteristics of his hotel which would emphasise the importance of WOM.

i) The intangibility of the hotel would make buyers likely to seek input WOM before choosing. Hotels are high on experience qualities.

ii) The high involvement of the buyer in the consumption process; and make hotel guests likely to communicate output WOM.

iii) The small business nature of the hotel meant little formalised marketing was undertaken and it was therefore reliant on recommendation for the customer acquisition.

The entrepreneur conducted a two stage research process to explore these propositions. The 
first stage was depth interviews, followed by a survey.

\section{Interviews}

The market research of clients comprised preliminary face-to-face interviews which formed the basis of a customer survey. Five guests were interviewed personally by the ownermanager and asked about their pre-purchase, and likely post-purchase behaviour in relation to the hotel: that is, how they chose the hotel, their decision making criteria, who or what influenced the process, and their likelihood to discuss their experiences (positive and negative), and with whom. Their comments informed the development of the questionnaire used in the second stage of the research.

\section{Questionnaire}

Following a pilot survey of 15 guests, a questionnaire was developed and distributed to 250 clients of whom 121 responded, a usable response rate of $48 \%$. The objectives of the questionnaire followed those of the earlier, face-to-face interviews in seeking to determine pre- and post-purchase behaviour, and the significance and types of WOM communications in those processes. On average tourists, largely from overseas, accounted for $70 \%$ of the hotel's occupancy. The owner considered this to be the most difficult market segment to reach by WOM communications as there were few obvious networks to use for such a widely dispersed group, compared to the second most important market segment of business travellers. The research was carried out in August and September, 1998, a time of year when the hotel was occupied mainly by tourists, in order to maximise response from this segment.

\section{WOM marketing strategy}

Following analysis of the results, the owner devised and implemented a marketing strategy which incorporated activities based on his interpretation of the research and the nature of WOM communications concerning the hotel in particular. He was interviewed in October 
1999. The second interview was a year after completion of the market research and asked him to describe his marketing strategies and the preliminary results of those strategies. Both interviews were semi-structured and subsequently transcribed and analysed using general analytical procedures.

\section{RESEARCH FINDINGS}

This summary will first consider the key market research findings relevant to the development of a marketing strategy and, secondly, the owner's actions in response to those findings. The first stage of the owner-manager's research was to explore the nature of the customer base. His results are described in the next section.

\section{Survey of hotel customers}

Tourists formed nearly 80 percent of respondents. Only 12 percent of respondents had booked directly with the hotel, with 85 percent using travel agents or tour operators, possibly because most respondents were overseas visitors. From Table 1 we can see the principal factors which influenced choice were location, price and facilities.

Table 1 Factors influencing hotel choice 


\begin{tabular}{|l|c|c|}
\hline $\begin{array}{l}\text { Factor and combination of } \\
\text { factors }\end{array}$ & $\begin{array}{c}\text { Number of } \\
\text { respondents }\end{array}$ & Percent of total \\
\hline Price and location & 26 & 25 \\
\hline Price, location and facilities & 25 & 24 \\
\hline Location & 21 & 20 \\
\hline Recommended & 15 & 15 \\
\hline Location and facilities & 9 & 2 \\
\hline Price & 2 & 2 \\
\hline Facilities & 2 & 2 \\
\hline Other & 2 & 1 \\
\hline Price and service & 1 & 100 \\
\hline Base & 103 & 2 \\
\hline
\end{tabular}

A combination of price and location was the most important influence on hotel choice, cited by a quarter of respondents. A further one in four of the respondents also thought that price and location were important but included an additional factor - facilities.

\section{Input WOM}

Respondents were asked if the hotel had been recommended to them. Just over half (52\%) confirmed that it had. The majority of these (77\%) had been recommended by a travel agent. Although it could be argued that these did not represent independent points of view, over $70 \%$ of respondents found the recommendation to be the most important, or quite an important factor in choosing the hotel. Travel agents might get paid a commision but the target audience appear to assume them to be independent of corporate influence (Buttle, 1998). However, over half (53\%) of all respondents claimed that they would not have chosen the hotel just because it was recommended to them.

\section{Output WOM}

Levels of satisfaction with the hotel were high, with $92 \%$ of respondents stating that they were satisfied with the hotel. This level of satisfaction is reflected in the number of guests 
claiming that they would engage in output WOM. All except one respondent agreed that they would discuss the trip afterwards, with over $90 \%$ of these agreeing that they would discuss the hotel specifically.

However, two particular challenges became evident from the analysis of output WOM (Table 2), compared to input recommendations.

The first was between targets and sources of WOM. The targets of output WOM were most likely to be friends and relatives (70\%), whereas this group was a relatively unimportant source of input WOM. By contrast, only 30\% of clients were likely to pass on recommendations to travel agents, who represented by far the largest source of input WOM.

Table 2 Source and Targets of Word Of Mouth

(Percent)

\begin{tabular}{|l|c|c|}
\hline Source / Target & At Input & Output intention \\
\hline $\begin{array}{l}\text { Friends, relatives and work } \\
\text { associates }\end{array}$ & 20 & 70 \\
\hline Travel agents & 77 & 30 \\
\hline Guidebook & 3 & 0 \\
\hline Total & 100 & 100 \\
\hline
\end{tabular}

\section{Base:121 Respondents}

The second problem relates to the content of the WOM. Output WOM recommendations were likely to mention factors which were not necessarily key influences in choosing the hotel. Whereas $70 \%$ of respondents considered location, price and facilities to be key factors in their choice of hotel, they intended to mention experiences such as the friendliness and cleanliness of the hotel more in their recommendations to others (see Table 3 below).

Table 3 Factor influencing favourable output WOM intentions 


\begin{tabular}{|l|c|c|}
\hline $\begin{array}{l}\text { Frequency of factors and } \\
\text { combination of factors }\end{array}$ & Frequency & $\begin{array}{c}\text { Percent of } \\
\text { total }\end{array}$ \\
\hline Friendly & 15 & 19 \\
\hline Location & 10 & 13 \\
\hline Price & 6 & 8 \\
\hline Price and location & 6 & 8 \\
\hline Price, friendly and location & 5 & 6 \\
\hline Cleaning & 5 & 6 \\
\hline Location and cleaning & 4 & 5 \\
\hline Service and room & 4 & 5 \\
\hline Service and cleaning & 2 & 5 \\
\hline Physical standards and cleaning & 1 & 4 \\
\hline Location and friendly & 1 & 1 \\
\hline Quality & $\mathbf{6 3}$ & $\mathbf{8 1}$ \\
\hline Total of factors & & \\
\hline
\end{tabular}

\section{WOM Marketing Strategy}

From his research, the owner concluded that WOM marketing could play a significant part in the hotel's marketing strategy:

"We were a 3 star hotel with nowhere to go. I needed to do something which would be novel, make us different in a very competitive market and generate word-ofmouth"

In particular, he decided to intervene in the recommending process by attempting to align the input WOM needs of potential customers with activities designed to encourage appropriate output WOM. 
The owner first addressed the imbalance between the high levels of input recommendations received by customers from travel agents, and the relatively low levels of output WOM returning to those agents as feedback. He instituted strategies to encourage a larger proportion of guests to tell their travel agents, and for the hotel to communicate guest satisfaction to the travel agents who had originally recommended the hotel. The use of an incentive encouraged guests to fill in comments cards, summaries of which were sent to the original booking source. Travel agents and guests were encouraged to recommend the hotel by both personal and psychological incentives. Complimentary room nights for travel agents, travel writers and other gatekeepers encouraged personal visits from these professional sources of recommendations. Travel agents were sent visual 'reminders of England' in the form of a miniature teddy bear, followed by regular mailings of honey to feed it. Believing that such visual aids improved the likelihood of WOM recommendations, the owner also gave a teddy bear to each guest on departure in the hope to remind them of the novel aspects of the hotel.

\section{Pre- and post-purchase WOM communications}

The owner also sought to align output WOM with input WOM needs by encouraging recommendations which mentioned location, facilities and price. Guests were given a detailed pocket-map of the vicinity of the hotel in relation to important tourist locations, including transport facilities and comparative costs. In addition to providing a service to guests, this acted as a visual aid for their recommendations which focused on the key input WOM topics as it also summarised the hotel's facilities and prices. As a result of the market research, the owner also decided to invest in facilities with a difference. Some of the hotel rooms were restored to exactly how they were in 1860 when the hotel opened, including furniture of the period. According to the owner, this would give guests even more reason to engage in WOM activities on their return home: 
"People like to talk about two things: their holidays, and the novel, something different. So we want to encourage them to talk about something that was different about their holiday. We are selling history now as part of our facilities. This has had a big impact which has generated a lot of word-of-mouth, a lot of comments in the press."

The owner recognised the strength of recommendations in other forms of marketing communications such as press releases and brochures, by quoting comments on value-formoney, facilities and location by independent sources including external rating organisations, trade affiliations as well as guests.

\section{WOM and involvement}

The owner sought to increase customers' likelihood to recommend the hotel by seeking ways in which guests could be more involved with the workings of the hotel. For example, he introduced an 'honesty bar' in one of the lounge areas where customers could serve themselves with drinks and be trusted to pay.

"For the first time they were in a sense part of the running of the hotel. We had recruited them into our staff... They like it because it's different and there's an element of trust in there."

\section{Negative WOM}

To reduce negative WOM, the owner invested in a comprehensive complaints handling procedure. Although it was normal industry practice for junior staff to handle complaints, he concluded that the overall responsibility should lie with a senior manager in order to allow guests direct access to decision-makers. Generous compensations became standard. The owner-manager believed that this had helped to not only decrease the number of complaints, but also quickly defuse those problems that did arise.

\section{CONCLUSIONS AND DISCUSSION}




\section{Evaluation of results}

Some literature (e.g. Barclays Review, 1997) implies that relying on WOM recommendations indicates an absence of marketing, or represents poor marketing practice. This entrepreneur has demonstrated that WOM marketing can form an integral part of a business strategy. Rather than regarding it as an uncontrollable form of marketing, he has attempted to use WOM as part of a positive approach to marketing his business. In doing so, he has built on existing strengths of entrepreneurial marketing rather than adopting more traditional marketing strategies from other contexts. He has attempted to turn the uncontrollable into a more proactive, controllable form.

Two areas have shown improvements in business performance. First, the use of a small gift did improve travel agent recommendations:

"We gave a teddy bear to travel agents that booked $x$ number of times and then they got a jar of honey through the post. ...Of the people that got it, we got three times as many bookings as from those that didn't. It was a way of permanently generating interest because we regularly sent them jars of English honey. When I stopped sending it for three months to some agents, sales from exactly that segment of agents went down, and then back up again when I restarted it."

Secondly, the honesty bar seemed linked to customer loyalty:

"The [honesty] bar only works for thirty percent of the hotel in a separate section so it was in some respect a controlled experiment. The repeat customers coming from that section are higher than the rest of the hotel."

Although the owner intends to evaluate other WOM marketing initiatives, the entrepreneurial nature of his business make it unlikely that detailed analysis will ever take place. However, the owner was confident of improvements because the research confirmed intuitive understandings of how the business worked:

"Fifty percent of our bookings were coming from recommendations. What we were doing in a small business way, intuitively, we now know on a more scientific basis, that we were right."

\section{Implications for other owner-managers and entrepreneurs}


Although the evidence of linkages between WOM marketing strategies and business improvement is limited, this case study does provide indications of how WOM processes affect a small business which ought to be of interest to other owner-managers and entrepreneurs. In particular, three areas of potential need in entrepreneurial marketing practice can be identified.

\section{The need to research WOM processes in specific contexts}

Consumer behaviour research suggests that the nature and extent of WOM activities are conditioned by their context. For example, the intangibility and high experience qualities of a service increases the likelihood of consumers seeking input WOM recommendations (Zeithaml, 1992). The degree of interaction between producers and consumers in the delivery of a service affects the degree of output WOM generated (Haywood, 1989). The research conducted by the entrepreneur confirmed the validity of such general points in the case of his hotel business as an intangible service with high consumer involvement. It also indicated several other factors more specific to his hotel which became fundamental to his marketing strategy. In particular the information concerning differences between input WOM sources and needs, and output WOM targets and content was crucial for marketing decisions. The research on which this was based was conducted personally by the entrepreneur and was neither sophisticated nor expensive.

This underlines the importance of understanding WOM processes as a prelude to making marketing decisions in an entrepreneurial context. Most entrepreneurs rely on their own personal experiences and intuitions to inform their marketing decisions (Carson et al., 1995). However, these may be inadequate to discover nuances of WOM processes amongst customers because these are non-commercial by definition, and normally excluding involvement by a self-interested entrepreneur. Informal entrepreneurial methods of gathering market information may not be effective in investigating the haphazard and non-commercial processes of WOM recommendations. Paradoxically, more formal information gathering may be required to understand the least formal of all marketing activities. 
The need to identify triggers to WOM activities

Research into the management of WOM activities is under-developed, especially amongst small businesses, the organisational type most dependent on it. Management interventions to influence WOM processes depend crucially on efforts to stimulate recommendations by 'unpaid advocates' (Buttle, 1998). The triggers of such recommendations are critical. The entrepreneur in this case study identified several ways to stimulate recommendations. He introduced visual aids for the hotel guests (informative maps) and travel agents (teddy bears). He attempted to increase feelings of involvement with the hotel (e.g. the honesty bar). He tried to create novel experiences which would trigger WOM comments (the historic decor of rooms). The idea of using stimuli including visual aids, involvement strategies unusual experiences and other techniques to stimulate WOM is not new (for example, Misner, 1994 and Wilson, 1991). However, the triggers used were specific to the marketing environment of the business. Other entrepreneurs would need to adapt the principles to their context.

The need to underpin WOM marketing with a defensive strategy

The value of 'offensive' marketing strategies to gain new customers can be undermined unless complemented by 'defensive' strategies designed to keep current customers (Fornell and Wernerfelt, 1988). WOM marketing is no exception. Negative WOM communications in the form of complaining behaviour by dissatisfied customers can quickly detract from efforts to manage positive WOM (Richins, 1983). A defensive WOM strategy in the form of complaint management procedures has been shown to be a good investment for large companies such as Coca Cola (TARP, 1981), but there is little evidence that small business owners consider this as an important issue.

The entrepreneur in this case study had learned the value of complaints' management the hard way:

"We lost the original process [of managing complaints] in a re-organisation and complaints went up 60 percent. The previous procedure was to have a duty manager hanging about mainly to deal with problems. When he went, complaints went up" 
As a result, the entrepreneur invested in procedures which attempted to diffuse dissatisfaction at an early stage. Such defensive WOM strategies are needed not only to promote customer loyalty but also to help minimise negative WOM which could affect new business.

In summary, this case study suggests that a WOM marketing strategy in the context of a small business would have three important ingredients:

1. Investigation of input and output WOM processes amongst customers and other important influencers of the business in specific contexts.

2. Development and implementation of an offensive WOM strategy by identifying activities that stimulate positive recommendations.

3. Development and implementation of a defensive WOM strategy that minimises negative communications.

By taking a systematic approach, the owner-manager has a clear opportunity to manage WOM recommendation to cost effective advantage.

\section{Acknowledgement}

The authors wish to acknowledge the participation and contribution of Alnur Dhanani, the entrepreneur who made this case study possible. We are also grateful for the comments of two anonymous JSBED reviewers for their constructive criticism.

\section{REFERENCES}

Arndt, J. (1967) 'Word-of-Mouth Advertising and Informal Communication' in Cox, D. (ed.) Risk Taking and Information Handling in Consumer Behaviour, Boston, Havard University.

Barclays Review (1997) Marketing and the Small Firm, May, London, Barclays Bank Plc.

Bayus, B.L. (1985) 'Word of Mouth: The Indirect Effects of Marketing Efforts', Journal of Advertising Research, Vol. 24, No. 3, June/July.

Bone, P.F. (1995) 'Word-of-Mouth Effects on Short-term and Long-term Product Judgements', Journal of Business Research, Vol. 21, No. 3, pp.213-223.

Buttle, F.A. (1998) Word-of-Mouth: Understanding and Managing Referral marketing, Proceedings of the Academy of Marketing Annual Conference, pp. 100-106, Sheffield Hallam University.

Carson, D., Cromie, S., McGowan, P. and Hill, J. (1995) Marketing and Entrepreneurship in SMEs, London, Prentice Hall. 
Culligan, C. (1995), 'Word-of-Mouth Becomes the True Measure of Ads', Marketing, Feb 9th, p.7

Day, J. (1998) 'Defining the Interface: A Useful Framework' in Hulbert, Day and Shaw, (eds.) Proceedings of the Academy of Marketing Symposia on the Marketing and Entrepreneurship Interface 1996-1998, Northampton: Nene University College.

Engel, J.F., Kegerris, R.J. and Blackwell, R.D. (1969) 'Word-of-Mouth Communication by the Innovator,' Journal of Marketing, Vol. 33, July, pp.15-19.

File, K.M., Judd, B.B. and Prince, R.A. (1992) 'Interactive Marketing: The Influence of Participation on Positive Word-of-Mouth and Referrals, Journal of Services Marketing, Vol. 6 No. 4, Fall, pp. 5-14.

Fornell, C. and Wernerfelt, B. (1988) 'A Model of Customer Complaint Management', Marketing Science, Vol. 7, No. 3, Summer, pp. 287-298

Haywood, M.K. (1989) 'Managing Word Of Mouth Communications', Journal of Services Marketing, Vol. 3, No. 2, Spring, pp. 55-67.

Heath, C. (1996), 'Do People Prefer to Pass Along Good Or Bad News? Valence and Relevance of News as Predictors of Transmission Propensity,' Organizational Behaviour and Human Decision Processes, Vol. 68, No 2, pp. 79-94.

Herr, P.M., Kardes, F.R. and Kim, J. (1991) 'Effects of Word-of-mouth and Product attribute Information on Persuasion: an Accessibility-Diagnocisticity Perspective', Journal of Consumer Research, Vol. 17, March pp. 454-462.

Kotler, P. (2000) Marketing Management, $10^{\text {th }}$. Edition, Englewood Cliffs, NJ: Prentice Hall. Misner, I.R. (1994) The World's Best Known Marketing Secret, New York, Bard \& Stephen.

Payne, A., Christopher, M., Clark, M., and Peck, H. (1995) Relationship Marketing for Competitive Advantage: Winning and Keeping Customers, Oxford, Butterworth-Heinemann.

Richins, M.L. (1983) 'Negative Word-of-Mouth by Dissatisfied Consumers: A Pilot Study,' Journal of Marketing, Vol. 47, Winter, pp. 68-78.

Shaw, E. (1997) 'The Real Networks of Small Business', in Deakins et al. (eds.) Small Firms and Entrepreneurship in the Nineties, London, Paul Chapman Publishing.

Sheth, J.N. (1971) 'Word-of-Mouth in Low-Risk Innovations, Journal of Advertising Research, Vol. 11, No. 3, June, pp.15-18

Stokes, D.R. (1997) 'A Lesson in Entrepreneurial Marketing from the Public Sector', Marketing Education Review, Vol.7, No.3, Fall, pp. 47-55. 
Stokes, D.R., Fitchew, S. and Blackburn, R.A.(1997) 'Marketing in Small Firms: a Conceptual Approach', Report to the Royal Mail, Small Business Research Centre, Kingston University.

TARP (1989), Measuring the Grapevine - Consumer Response and Word-of-Mouth, Technical Assistance Research Programs Inc, Office of Consumer Affairs, Washington DC, USA.

Wilson, J.R.. (1996) Word of Mouth Marketing, New York, John Wiley \&Sons.

Zeithaml V. A., (1992) 'How Consumer Evaluation Processes Differ Between Goods and Services' in Donelly and George, (eds.) Marketing Services, Chicago, American Marketing Association, pp.186-190.

Previously Head of School of Marketing at Kingston Business School, Wendy Lomax is now Professor of Marketing for the Food, Drink and Related Industries at Cranfield University. Her extensive marketing management experience has been followed by academic study focusing on loyalty issues such as cannibalisation and word-of-mouth recommendation. 